\title{
The kleptoparasitic and commensal association of Dalmatian Pelicans Pelecanus crispus with Great Cormorants Phalacrocorax carbo
}

\author{
Kleptoparasitism och kommensalism mellan \\ krushuvad pelikan Pelecanus crispus \\ och storskarv Phalacrocorax carbo
}

\author{
Hans Källander \\ Villavägen 6, 24165 Harlösa, Sweden | hans.kallander@telia.com
}

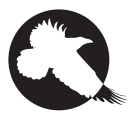

the Association between Dalmatian Pelicans Pelecanus crispus and Great Cormorants Phalacrocorax carbo was studied at three Greek sites, Megali Prespa, Kerkini and Karla. At Prespa, the two species seemed to use each other mutually: pelicans benefited from fish that tried to escape from the cormorants by swimming towards the surface while cormorants used the pelicans as a cue to the presence of fish shoals. When a pelican flew towards a cormorant, other cormorants immediately flew there and dived instantly. The association usually was very brief, lasting only a mean of 114 seconds. Pelicans mostly foraged singly or in small groups (mean 3.2 individuals) and often there were also few cormorants (median 6). Kleptoparasitism was recorded at all three sites, but at Kerkini and Karla, pelicans associated with the huge fishing flocks of cormorants and predominantly kleptoparasitized them. Around $20 \%$ of attacks were successful. Thirty-one attacks were very violent with the pelican holding the cormorant until it dropped its fish.

Keywords: interspecific association | kleptoparasitism | commensalism | piscivory | flock foraging 


\section{Introduction}

Kleptoparasitism, the stealing of food from other individuals, has attracted much interest among ornithologists and many hundreds of papers on the topic exist. Several reviews have been devoted to this foraging behaviour (Brockmann \& Barnard 1979, Furness 1987, Morand-Ferron et al. 2007, Iyengar 2008). Barnard \& Thompson (1985) analysed in great detail the kleptoparasitic association between Black-headed Gulls Croicocephalus ridibundus on the one hand and Northern Lapwings Vanellus vanellus and European Golden Plovers Pluvialis apricaria on the other. Both intraspecific and interspecific kleptoparasitism is a common foraging method in both terrestrial and aquatic environments and may have negative effects on the host (Stienen et al. 2001) and positive effects on the parasite, e.g. by promoting nestling growth (García et al. 2013).

Commensalism, in which an individual benefits from associating with individuals of another species without having any negative impact on the latter's food intake is equally common and the literature is similarly extensive. In the terrestrial environment, it usually takes the form of 'flushing' or 'beating' by which insects and other arthropods become exposed because of the host's movements; in aquatic environments it usually means that food particles become available to the commensal because of the host's feeding activities. As examples one could mention Little Grebes Tachybaptus ruficollis that associate with dabbling ducks (Siegfried 1971, Robson 1975) or various waterbirds that associate with swans Cygnus spp. (Bailley \& Batt 1974, Beven 1980, Merilä \& Ohtonen 1987, Källander 2005, Dijksen \& Ouweneel 2005, Gyimesi et al. 2012). Byrkjedal et al. (1997) described how Velvet Scoters Melanitta fusca that were digging for echinoderms in a sandy substrate thereby disturbed large numbers of polychaete worms that were exploited by Red-necked Grebes Podiceps grisegena. Another interesting association is that between neotropical otters Lontra longicaudus which drove fish in front of them so that various species of piscivorous birds got access to the fish (D'Angelo \& Sazima 2014). In the marine habitat, a variety of birds associate with whales and dolphins (reviewed by Evans 1982; Hodges \& Woehler 1995, Camphuysen \& Webb 1999, Orgeira 2004, Anderson \& Lovvorn 2008, Hebshi et al. 2008, Rossi-Santos \& Flores 2009, Rudd et al. 2011).

Fish are often relatively large (especially in relation to the size of a bird's bill) and take long to swallow, which make both intraspecific and interspecific kleptoparasitism a common foraging method among piscivores. In the present contribution the kleptoparasitic and commensal association of Dalmatian Pelicans Pelecanus crispus with Great Cormorants Phalacrocorax carbo is described.

\section{Study areas}

Observations were carried out at Megali Prespa in north-western Greece mainly in June and early July in 1991, 1993, 1995 and in May 2015 and 2018, at the Karla reservoir in central Greece in January 2016 and at Kerkini reservoir and the river Strymonas in northern Greece in March 2013 and May 2018.

Megali Prespa is a deep lake (maximum $54 \mathrm{~m}$ ) with clear water, shared between Greece, Albania and North Macedonia. It is surrounded by mountains but nearer to its southern end it is shallower. The pelicans nest in Mikri Prespa but nearly all of their feeding takes place in Megali Prespa and the same is true for cormorants. So, every day they have to fly across the c. $1 \mathrm{~km}$ wide isthmus that separates the two lakes. They often fly far out on the $176 \mathrm{~km}^{2}$ large lake and in recent years much feeding has taken place near the large island of Golem Grad in North Macedonia.

At Kerkini, the situation differs considerably from that at Prespa. Kerkini was created in 1932 by the building of a large dam across the river Strymonas. First of all, the water is much less clear and the cormorants breed at considerably larger colonies than at Prespa. Thus, in 2013, 5,600 cormorants were breeding at Kerkini. Even though cormorant numbers have since decreased to about 4,500 ( $\mathrm{T}$ Naziridis pers. comm.), fishing flocks regularly contained more than a thousand cormorants on the lake and several hundred on the River Strymonas.

Karla was a natural lake that was partly drained from 1962 to 1965 . Later (in the 1990 s to 20oos) a large reservoir (mainly for irrigation purposes but also for wildlife) was built around part of the former lake bed. The lake's maximum depth is less than two metres. Part of it is surrounded by dykes constructed from rocks and stones. The surrounding lowland is crossed by drainage canals. The lake's water level is regulated and 
the lake contains a lot of fish. Its fish fauna is dominated by cyprinids. It also holds one of six Greek breeding sites for Dalmatian Pelicans and three for Great White Pelicans Pelecanus onocrotalus.

\section{Methods}

Pelicans were observed from the lake shores and the banks of the reservoirs with the aid of telescopes (Kowa TSN with a $20 \times$ ocular during 1991-1995 and with a Carl Zeiss diascope 85 TL with a 20-60 $\times$ zoom in all later years). During the first years, observations were talked into a small tape recorder and later transcribed; in later years the material was entered directly into note books. At Prespa the focus was on the association between pelicans and cormorants whether kleptoparasitic or commensal. For this reason, the duration of the feeding associations was measured and the number of the two species recorded. At the two other sites, the studies were concentrated on kleptoparasitism although commensalism was also observed. At all three sites the kleptoparasitism was recorded as number of attacks on the cormorants that were successful, i.e. resulted in the pelican stealing the fish from the cormorant. Commensalism was much more difficult to record and therefore no hard data on its occurrence could be obtained. However, the number of 'strikes' seen at Megali Prespa and reported below probably largely represent cases of commensalism. It should be emphasized that observation distances were often long, about a hundred meters at the Strymonas river and often many hundred metres elsewhere.

\section{Results}

\section{MEGALI PRESPA}

At Megali Prespa the association between pelicans (both Dalmatian and Great White Pelicans) appeared to be mutual: pelicans were attracted to cormorants and benefited from fish that the cormorants made available by their deep-diving fishing method, while cormorants seemed to use the behaviour of the pelicans to locate fish shoals. Pelicans were most often foraging singly or in small groups of just a few individuals (mean $=3.2$, $\mathrm{SD}=2.08, \mathrm{n}=124)$. When a pelican rushed or flew towards a cormorant in a very typical posture with neck erect and held slightly forward, the bill pointing obliquely downwards, then this acted as a strong cue to both other cormorants and other pelicans, so within seconds a small group gathered around the first pelican. The number of cormorants was usually rather low (the median value being 6). In just one instance their number reached 190 and this situation also differed in that pelicans seemed to engage to a great deal in kleptoparasitism.

Cormorants nearly always dived instantly on landing. Sometimes a pelican threatened another pelican and drove it away from the cormorant group. Fishing sessions were usually of short duration lasting a mean of only $114 \mathrm{~s}$. Either the pelican or the cormorants then flew off, often to another actively fishing group. The hovering low over the surface by Yellow-legged Gulls Larus michahellis also made pelicans fly to the site.

Out of 274 recorded 'strikes', pelicans swallowed a fish on 146 (53.3\%). Most of these instances were no doubt commensal, i.e. the pelicans got fish that had tried to escape from the cormorants by swimming upwards towards the surface. Indeed, from a high vantage point west of the lake it was on several occasions possible to see the shoals just below the surface close to the place where a cormorant had surfaced. In contrast, the attacks by the pelican rather seemed to make the shoals return into deeper water which may explain the short duration of the fishing bouts.

Kleptoparasitism was established c. 40 times with attacks where the pelican succeeded in securing the fish on nine occasions (c. 18\%). Once a big fish was lost into the water by both the cormorant and the pelican. However, the number of times that kleptoparasitism could be established with certainty was probably underestimated, because on many occasions a pelican stroke close to a surfacing cormorant and the pelican swallowed while the cormorant surfaced without a fish. From the high hills to the west of the lake one could see through the clear water of Megali Prespa how pelicans followed a diving cormorant, changing direction as the cormorant did so. Those kleptoparasitic attacks where a pelican got the fish involved relatively large fish.

\section{KERKINI}

At Kerkini, the situation differed considerably from that at Prespa. The large flocks of cormorants were almost always accompanied by numerous Dalmatian Pelicans 


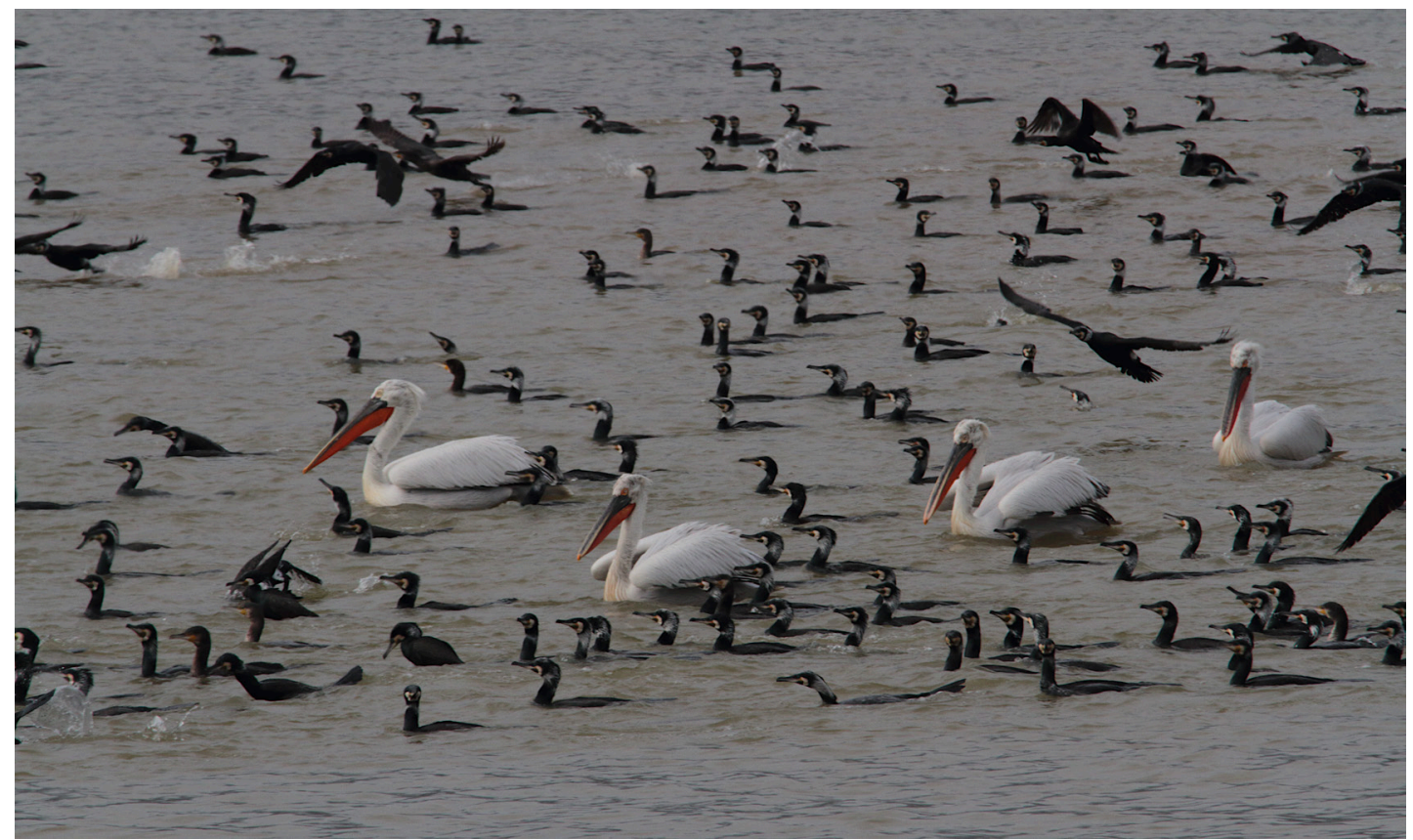

FIGURE 1. Four Dalmatian Pelicans Pelecanus crispus surveying a flock of not very active Great Cormorants Phalacrocorax carbo. - Fyra krushuvade pelikaner Pelecanus crispus granskar en flock av inte särskilt aktiva storskarvar Phalacrocorax carbo.

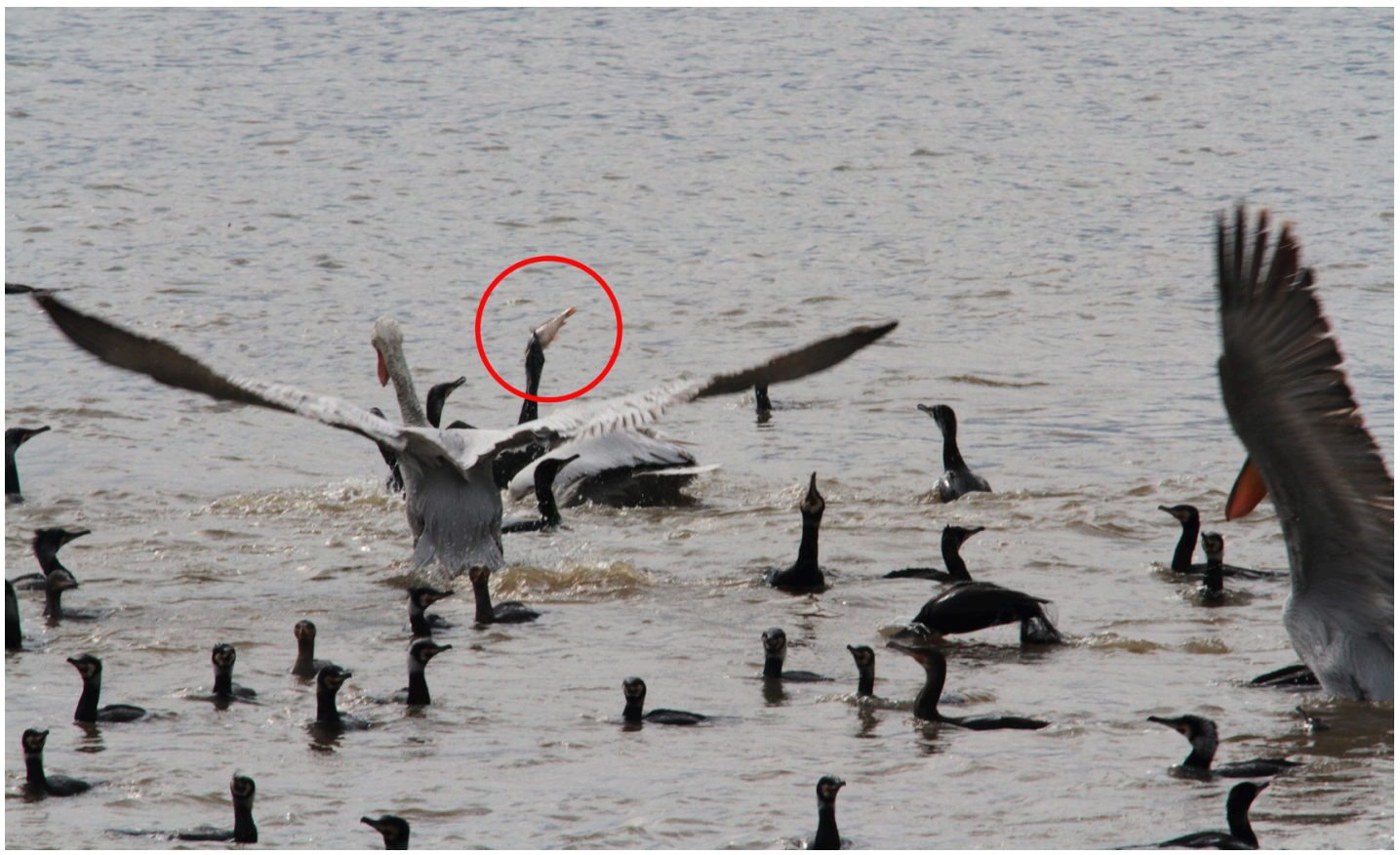

FIGURE 2. Three Dalmatian Pelicans Pelecanus crispus starting an attack on a Great Cormorant Phalacrocorax carbo with a fish (encircled). - Tre krushuvade pelikaner Pelecanus crispus startar en attack mot en storskarv Phalacrocorax carbo med fisk i näbben (röd ring).. 
which were spread out among the cormorants (Figure 1). The pelicans followed the cormorants as they swam or flew to a new position on the lake. When a cormorant captured a fish, a pelican would immediately make a short flight towards it which usually made other pelicans join in and often there was much movement and excitement (Figure 2). This, together with often long observation distances often made it difficult to determine the outcome of the attacks with certainty. However, it was usually possible to see the pelican's typical swallowing movements. Overall, pelicans were successful in c. $19 \%$ of their attacks on cormorants at Kerkini.

A smaller material was obtained from the River Strymonas, where the interactions between cormorants and pelicans could be studied at closer range. In early summer, cormorants fly and swim upstream the river in large numbers and are followed by White Storks Ciconia ciconia, Black Storks C. nigra, Eurasian Spoonbills Platalea leucorodia, Grey Herons Ardea cinerea, Little Egrets Egretta garzetta and Yellow-legged Gulls, all of which try to use the cormorants commensally by following the river banks and shifting to the bank closest to the cormorants. Pelicans also followed the cormorants and kleptoparasitized them. In 2018, 4 out of 13 'strikes' by Dalmatian Pelicans towards pelicans were successful (31\%). However, if one includes the number of flights towards cormorants that were not followed by a strike, i.e. when the pelican interrupted its attack at an early stage, their success rate was very much lower.

Pelicans also took advantage of the cormorants as they drove small fish towards the shore or into vegetation. Many positive strikes were seen in such situations (commensalism). How successful the pelicans were at obtaining fish by commensalism unfortunately could not, however, be determined. Flocks of Black-headed Gulls, which plunge-dived for small fish, often also accompanied the cormorants. As an example, more than 20 such positive dives by gulls were recorded over a flock of cormorants that followed small fish into a shallow area.

\section{KARLA RESERVOIR}

As at Kerkini, pelicans associated closely with flocks of cormorants and often flew together with them to the place where the cormorants landed. Pelicans attacked cormorants that surfaced with a fish and, as at Kerkini, an attack by a pelican always made other pelicans head for the same cormorant. Out of 184 attacks recorded
$41(22.3 \%)$ were successful (I did not record attacks that were not followed by a strike). In these cases, fish were relatively large. As at Prespa, cormorants and pelicans reacted to Yellow-legged Gulls that hovered low over the surface and quickly flew to the spot. A similar observation was made by Jönsson (1984) who studied groups of European Shags Phalacrocorax aristotelis that were fishing off the island of Skopelos in the northern Sporades. The Shags were kleptoparasitized by Yellow-legged Gulls. When the Shags ceased fishing, the gulls started searching for fish shoals on their own. When one was found, their hovering and calling immediately recruited the Shags which began exploiting the shoal and were again kleptoparasitized by the gulls.

\section{SOME GENERAL OBSERVATIONS}

Overall some $20 \%$ of kleptoparasitic attacks resulted in the pelican obtaining the fish. Twice a pelican was seen trying to obtain a fish from a cormorant in flight but with no success. Cormorants made no attempts at avoiding being kleptoparasitized. Only a couple of times they were seen threatening or trying to bite a pelican. In fact, at Prespa cormorants reacted to a striking pelican by flying to it and immediately diving under it.

At Kerkini, Dalmatian Pelicans were also seen associating with flock-fishing Pygmy Cormorants Microcarbo pygmaeus. About 200 Pygmy Cormorants were fishing in a shallow, vegetated bay and were followed by some ten pelicans. Probably the cormorants' activities made fish available to the pelicans but one instance of a (successful) kleptoparasitic attack was also recorded. Several attempts at intraspecific kleptoparasitism among pelicans were also observed, but only two were successful.

\section{Discussion}

The association between Dalmatian Pelicans and Great Cormorants appear to be a very close one. The observations at Prespa suggest that at this lake the association may benefit both parties: the pelicans by increasing their intake of fish (Crivelli \& Visi 1981, Maximidi et al. unpublished data) and the cormorants by finding fish shoals with the aid of pelicans. Although kleptoparasitism was very common at the two other sites, commensalism also occurred quite commonly.

Even if there is a cost to the cormorants in the form of fish lost to kleptoparasitic pelicans, the cormorants 
seem to have no possibility to avoid this cost. However, as the number of cormorants always was much larger than the number of pelicans, the individual loss no doubt was negligible especially at the two sites (Kerkini and Karla) where cormorants formed huge fishing flocks. Intraspecific kleptoparasitism between cormorants, which was relatively common, was probably more costly for the cormorants than was that of the pelicans' but the formation of large fishing assemblies by cormorants likely increases capture efficiency enough to greatly outweigh this cost (Källander 2013).

The attacks on cormorants were often very fierce and on a total of 31 occasions (all three study sites together) a pelican was seen holding the cormorant until it dropped its fish (only once a cormorant managed to keep it). To use an anthropomorphic term, the way that pelicans handled the cormorants was rather cruel. They held them across their necks and heads and once across the body and once in the wing, the cormorant struggling to get loose. This violent treatment of the cormorants has also been seen at Lake Joaninna in western Greece (Catsadorakis 2002).

It seems that the association between pelicans and cormorants is a very common and wide-spread phenomenon. Apart from the localities studied here, it has also been mentioned by Romashova (1994) from the Volga delta and P-E Jönsson (pers. comm.) also saw the close association between Dalmatian Pelicans and cormorants in the Donau delta.

Kleptoparasitism has also been observed in the American White Pelican Pelecanus erythrorhynchos (O'Malley \& Evans 1983, Anderson 1991). In both the cited studies, these attacks were directed at flocks of Double-crested Cormorants Phalacrocorax auritus. In the former study only two out of ten attacks were successful while 26 of 52 attacks (33.3\%) were so in the latter. These figures agree rather well with those obtained in the present study, which seems to be the first one to quantify kleptoparasitism as a feeding method in the largest species of pelican, the Dalmatian Pelican.

\section{References}

Anderson JGT. 1991. Foraging behavior of the American White Pelican (Pelecanus erythrorhyncos) in Western Nevada. Colonial Waterbirds 14: 166-172. https://doi.org/10.2307/1521506

Anderson EM \& Lovvorn JR. 2008. Gray Whales may increase feeding opportunities for avian benthivores. Marine Ecology Progress Series 360:291-296. https://doi.org/10.3354/mepso7359
Bailley BRO \& Batt BDJ. 1974. Hierarchy of waterfowl feeding with Whistling Swans. Auk 91: 488-493. https://doi. org/10.2307/4084468

Barnard CJ \& Thompson DBA. 1985. Gulls and plovers. The ecology and behaviour of mixed-species feeding groups. Oxford University Press, Oxford.

Brockmann HJ \& Barnard CJ. 1979. Kleptoparasitism in birds. Animal Behaviour 27:487-514. https://doi. org/10.1016/0003-3472(79)90185-4

Byrkjedal I, Eldøy S, Grundetjern S \& Løyning MK. 1997. Feeding association between Red-necked Grebes Podiceps griseigena and Velvet Scoters Melanitta fusca in winter. Ibis 239:245-250. https:// doi.org/10.1111/j.1474-919X.1997.tbo4503.x

Camphuizen CJ \& Webb A. 1999. Multi-species feeding associations in North Sea seabirds: jointly exploiting a patchy environment. Ardea 87:177-198.

Catsadorakis G. 2002. The book of pelicans. Society for the Protection of Prespa, Agios Germanos.

Crivelli A \& Visi O. 1981. The Dalmatian Pelican, Pelecanus crispus Bruch 1832, a recently world-endangered species. Biological Conservation 20: 297-310. https://doi.org/10.1016/0006-3207(81)90016-1

D’Angelo GB \& Sazima I. 2014. Commensal association of piscivorous birds with foraging otters in southeastern Brazil, and a comparison with such a relationship of piscivorous birds and cormorants. Journal of Natural History 48:241-249. https://doi.org/10.1080/002 22933.2013.808714

Dijksen AJ \& Ouweneel GL. 2005. Commensalisme van Geoorde Futen bij Knobbelzwanen. Limosa 78:155-156.

Evans PGH. 1982. Associations between seabirds and cetaceans: a review. Mammal Review 12:187-206. https://doi. org/10.1111/j.1365-2907.1982.tbooo15.x

Furness RW. 1987. Kleptoparasitism in seabirds. Pp 77-100 in: Seabirds: feeding ecology and role in marine ecosystems (Croxall JP, ed). Cambridge University Press, Cambridge.

García GO, Becker CH \& Favero M. 2013. Intraspecfic kleptoparasitism improves chick growth and reproductive output in Common Terns Sterna hirundo. Ibis 155:338-347. https://doi.org/10.1111/ ibi.12019

Gyimesi A, van Lith B \& Nolet BA. 2012. Commensal foraging with Bewick's Swans Cygnus bewickii doubles instantaneous intake rate of Common Pochards Aythya ferina. Ardea 100:55-62. https://doi. org/10.5253/078.100.0109

Hebshi AJ, Duffy DC \& Hyrenbach KD. 2008. Associations between seabirds and subsurface predators around Ohau, Hawaii. Aquatic Biology 4: 89-98. https://doi.org/10.3354/abooo98

Hodges CL \& Woehler EJ. 1995. Associations between seabirds and cetaceans in the Australian sector of the southern Indian Ocean. Marine Ornithology 22:205-212. Available at https://www. marineornithology.org/content/get.cgi? $r n=306$

Iyengar EV. 2008. Kleptoparasitic interactions throughout the animal kingdom and a re-evaluation, based on participant mobility, of the conditions promoting the evolution of kleptoparasitism. Biological Journal of the Linnean Society 93:745-762. https://doi. org/10.1111/j.1095-8312.2008.00954.x

Jönsson P-E. 1984. Herring Gulls exploiting and 'helping' feeding Shags. British Birds 77:121-122.

Källander H. 2005. Commensal association of waterfowl with feeding swans. Waterbirds 28:326-330. https://doi.org/10.1675/1524-4695( 2005)028[0326:CAOWWF]2.0.CO;2

Källander H. 2013. Intraspecific kleptoparasitism in flock-fishing Great Crested Grebes Podiceps cristatus and Great Cormorants Phalacrocorax carbo - a cost to participants? Ornis Hungarica 21:36-40. https://doi.org/10.2478/orhu-2013-0014 
Merilä E \& Ohtonen A. 1987. Mixed feeding of Whooper Swans and ducks during migration. Suomen Riista 34:52-58. (In Finnish with English summary.)

Morand-Ferron J, Lefebre L \& Sol D. 2007. Food stealing in birds: brain or brawn. Animal Behaviour 74:1725-1734. https://doi. org/10.1016/j.anbehav.2007.04.031

Orgeira JL. 2004. Asociaciones entre aves marinas y cetáceos en el Océano Atlántico Sur y Antártida. Orntologia Neotropical 15:163-171. Available at https://sora.unm.edu/node/119573

O'Malley JBE \& Evans RM. 1983. Kleptoparasitism and associated foraging behaviors in American White Pelicans. Colonial Waterbirds 6:126-129. https://doi.org/10.2307/1520979

Robson RW. 1975. Feeding association between Little Grebes and feral domestic ducks. British Birds 68:293-294.

Romashova AT. 1994. Breeding biology and feeding ecology of Pelecanus crispus and Pelecanus onocrotalus in the northern Caspian. Pp 99-114 in: Pelecans in the former U.S.S.R. (Crivelli AJ, Krivenko VG \& Vinogradov KG, eds). IWRB Special Publication 27. International Waterfowl and Wetlands Bureau, Slimbride.
Rossi-Santos M \& Flores P. 2009. Feeding strategies of the Guiana Dolphin Sotalia guianenses. The Open Marine Biology Journal 3:70-76. https://doi.org/10.2174/1874450800903010070

Rudd AR, Titmus AJ, Gisborne B \& Heath JP. 2011. Association of Marbled Murrelets Brachyramphus marmoratus with foraging Gray Whales Eschrichtius robustus on the southwest coast of Vancouver Island, British Columbia. Marine Ornithology 39:261-266. Available at https://www.marineornithology.org/content/get.cgi?rn=944

Siegfried R. 1971. Feeding association between Podiceps ruficollis and Anas smithii. Ibis 113:236-238. https://doi.org/10.1111/j.1474919X.1971.tbo5150.x

Stienen EWM, Brenninkmeier A \& Geshiere CE. 2001. Living with gulls: The consequences of Sandwich Terns breeding in association with Black-headed Gulls. Waterbirds 24:68-82. https://doi. org/10.2307/1522245

\section{Svensk sammanfattning}

Under åtta besök i Grekland under perioden 1991 till 2018 studerade jag hur krushuvade pelikaner Pelecanus crispus associerade sig med storskarvar Phalacrocorax carbo på tre lokaler: Megali Prepa i nordvästra Grekland, Kerkini i norra Grekland och Karla i den centrala delen av landet. Pelikanerna utnyttjade skarvarna antingen kommensalt eller kleptoparasitiskt. I Megali Prespa föreföll associationen mellan pelikaner och skarvar vara ömsesidig: skarvarna utnyttjade pelikanerna för att finna fiskstim medan pelikanerna drog nytta av skarvarna, dels genom att dessa skrämde fisk mot ytan, dels genom att kleptoparasitera dem. Associationen mellan pelikaner och skarvar var vanligen kortvarig, och varade i medeltal blott 114 sekunder, varpå antingen skarvarna eller pelikanerna lämnade platsen och flög till en ny grupp av pelikaner och skarvar. Den korta tiden associationen varade kan ha berott på att pelikanerna skrämde fiskarna nedåt mot djupare vatten. Antalet pelikaner i grupperna var lågt, i medeltal endast 2,4 och i allmänhet var antalet skarvar likaledes lågt (medianvärde 6). Grupperna bildades oftast genom att en pelikan flög eller "rushade" mot en uppdykande skarv. Pelikanen hade då en sträckt hållning med halsen något framåtsträckt och med näbben pekande snett nedåt. När den nådde skarven högg den oftast mot vattnet varvid den ibland lyckades ta en fisk. Av 274 "hugg" mot ytan lyckades pelikanen 146 gånger $(53,3 \%)$ ta en fisk. Grupper bildades snabbt då andra pelikaner och framför allt skarvar reagerade på den anflygande pelikanens beteende och anländande skarvar dök nästan alltid omedelbart efter landningen.

Pelikanerna utnyttjade också skarvarna kleptoparasitiskt, dvs genom att stjäla fisk från dem. I $18 \%$ av dessa kleptoparasitiska attacker lyckades pelikanen stjäla fisken, men det är möjligt att denna siffra är en smula i underkant, ty många gånger då en pelikan huggit och svalt en fisk, kom en skarv upp alldeles i närheten utan att själv ha byte. Från en utsiktspunkt väster om sjön kunde man se fiskstimmen i det klara vattnet och också hur en pelikan simmande följde en dykande skarv när denna ändrade riktning.

Kerkini och Karla skiljer sig i flera avseenden mycket från situationen vid Prespa. Båda lokalerna är konstgjorda, Kerkini genom att floden Strymonas har dämts upp. Karla är en tidigare våtmark som restaurerats och som tjänar det dubbla syftet att förse jordbruksmark med vatten och att skapa ett rikt fagelliv. Båda lokalerna är fiskrika och hyser häckande krushuvade pelikaner och i synnerhet Kerkini har mycket stora skarvkolonier (för närvarande omfattande över 4500 par). På båda lokalerna låg fokus på att försöka kvantifiera kleptoparasitismen. I Kerkini uppgick skarvflockarna ofta 
till betydligt över 1000 fåglar. Pelikanerna följde dessa och bevakade dem noga (figur 1). När en skarv fått en stor fisk som var svår att svälja snabbt, attackerades den omedelbart av en eller oftast flera pelikaner och det blev ett tumult (figur 2), där utgången av attackerna ofta var svåra att avgöra på grund av långa avstånd. Cirka $19 \%$ av attackerna resulterade i att en pelikan tog fisken. När skarvflockarna lyfte eller simmade till en ny plats följde pelikanerna med. Ibland simmade skarvarna in i strandvegetationen eller drev småfisk framför sig på grunt vatten. I sådana situationer iakttogs också kommensalism, dvs pelikanerna fick åtkomst till fisk som försökte undfly skarvarna. Pelikaner sågs också följa en stor flock med dvärgskarvar Microcarbo pygmaeus i tätare vegetation och en pelikan lyckades också stjäla en fisk från en dvärgsskarv. Situationen vid Karla var ganska likartad den vid Kerkini. Pelikanerna följde ofta skarvflockar när dessa flög ut på vattnet för att bedriva sitt flockfiske. I 41 av 184 attacker (22,3\%) lyckades pelikanerna stjäla en fisk. Här, liksom vid Prespa, flög pelikaner också till platsen där en medelhavstrut ryttlade. På motsvarande sätt reagerade toppskarvar Phalacrocorax aristotelis utanför ön Skopelos (Jönsson 1972). Krushuvade pelikaner verkar regelbundet utnyttja skarvar och beteendet har iakttagits också i Volgadeltat och Donaudeltat. Även den amerikanska vita pelikanen Pelecanus erythrorhynchos har setts kleptoparasitera öronskarvar Phalacrocorax auritus (O'Malley \& Evans 1983, Anderson 1991).

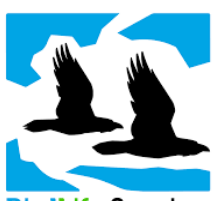

BirdLife Sverige

Ornis Svecica (ISSN 2003-2633) is an open access, peer-reviewed scientific journal published in English and Swedish by BirdLife Sweden. It covers all aspects of ornithology, and welcomes contributions from scientists as well as non-professional ornithologists. Accepted articles are published at no charge to the authors. Read papers or make a submission at os.birdlife.se.

Ornis Svecica (ISSN 2003-2633) är en fritt tillgänglig granskad vetenskaplig tidskrift som ges ut på svenska och engelska av BirdLife Sverige. Den täcker ornitologins alla områden och välkomnar bidrag från såväl forskare som icke-professionella ornitologer. Accepterade uppsatser publiceras utan kostnad för författarna. Läs uppsatser eller skicka in ditt bidrag på os.birdlife.se. 